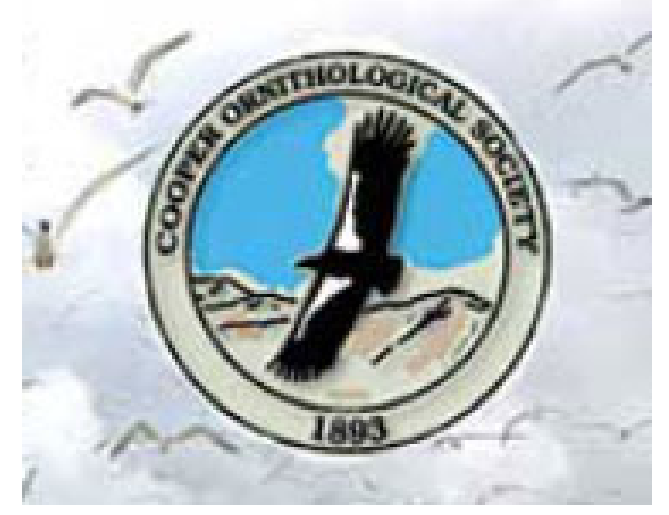

Sex Differences in Nest Visitation by Chick-Rearing Marbled Murrelets Author(s): Russell W. Bradley, Laura A. McFarlane Tranquilla, Brett A. Vanderkist and Fred Cooke

Reviewed work(s):

Source: The Condor, Vol. 104, No. 1 (Feb., 2002), pp. 178-183

Published by: University of California Press on behalf of the Cooper Ornithological Society Stable URL: http://www.jstor.org/stable/1370355

Accessed: $21 / 06 / 2012$ 12:31

Your use of the JSTOR archive indicates your acceptance of the Terms \& Conditions of Use, available at http://www.jstor.org/page/info/about/policies/terms.jsp

JSTOR is a not-for-profit service that helps scholars, researchers, and students discover, use, and build upon a wide range of content in a trusted digital archive. We use information technology and tools to increase productivity and facilitate new forms of scholarship. For more information about JSTOR, please contact support@jstor.org. 


\title{
SEX DIFFERENCES IN NEST VISITATION BY CHICK-REARING MARBLED MURRELETS
}

\author{
Russell W. Bradley', Laura A. McFarlane Tranquilla, Brett A. Vanderkist and Fred Cooke \\ Centre for Wildlife Ecology, Department of Biological Sciences, Simon Fraser University, Burnaby, \\ $B C$ V5A 1S6, Canada
}

Abstract. We report a significant male bias in dawn and dusk nest visitations of breeding, radio-marked Marbled Murrelets (Brachyramphus marmoratus) during the chick rearing period in Desolation Sound, British Columbia, Canada, from 1998-2000. Overall visitation rates of males during chick rearing were 1.3 times greater than those of females. Dusk visitation rates by males with active nests were 1.8 times greater than those of females. Male visitation rates were similar between early and late chick rearing, both within and among individuals. However, female visitation rates during late chick rearing were significantly lower than female rates early in rearing, both within and between individuals. In addition, between-sex comparisons of nest visitation during early and late chick rearing showed significant reductions in female effort relative to males, only during late chick rearing. These results suggest that male birds may provision chicks more often than females, especially during the last half of chick rearing. These findings offer a behavioral explanation for the annual male bias of birds flying inland during the chick rearing period at Theodosia Inlet in Desolation Sound from 1994-1999. Although female-biased provisioning has been documented in several species, male-biased provisioning has not been widely reported in other alcids.

Key words: Brachyramphus marmoratus, British Columbia, male bias, Marbled Murrelet, provisioning, radio-telemetry, sex ratio.

\section{Diferencias de Sexo en la las Visitas al Nido en Brachyramphus marmoratus durante la Crianza de Pichones}

Resumen. Presentamos evidencia sobre un sesgo hacia los machos en las visitas a nidos efectuadas al amanecer y el crepúsculo durante la crianza de pichones, en individuos marcados con radios en Desolation Sound, Columbia Británica, Canadá, entre 1998-2000. La tasa de visitas de los machos fue 1.3 veces mayor que la de las hembras. La tasa de visitas de los machos al crepúsculo con nidos activos fue 1.8 veces mayor que las hembras. La tasa de visitas de los machos fue constante a través del período de crianza, tanto para un mismo individuo como entre individuos. Sin embargo, la tasa de visitas de las hembras fue significa-

Manuscript received 27 March 2001; accepted 25 September 2001.

${ }^{1}$ Present address: Point Reyes Bird Observatory, 4990 Shoreline Highway, Stinson Beach, CA 94970. E-mail: rbradley@prbo.org tivamente menor al final que al inicio de la crianza, tanto para un mismo individuo como entre individuos. Además, la tasa de visitas de las hembras fue menor que la de los machos al final de la crianza. Estos resultados sugieren que los machos abastecen a los pichones en mayor medida que las hembras, especialmente en la última parte de la crianza. Asimismo, los resultados ofrecen una explicación conductual para la dominancia anual de machos volando tierra adentro durante la crianza en Theodosia Inlet, Desolation Sound, entre 1994-1999. En pocas ocasiones se ha descripto abastecimiento paternal en los álcidos, donde principalmente las hembras se encargan del abastecimiento.

In altricial birds, biparental care is common. Successful fledging of a chick may often require biparental care where the growth seasons are relatively short, young are usually accessible to predators, and food is widely and unpredictably distributed (Clutton-Brock 1991). However, within biparental bird species, differential provisioning by sex is highly variable. Among passerines, biased provisioning by either sex has been widely documented, as has equal provisioning effort (Pettingill 1970). In monogamous seabirds, total parental investment by males equals and sometimes outweighs that of females (Fasola and Saino 1995). The relative investment by each sex in parental care can reflect trade-offs, energy constraints, and life history strategy for a given species (Roff 1992).

Marbled Murrelets (Brachyramphus marmoratus) are nearly unique among alcids and other seabirds in that they nest predominantly at cryptic sites in large, old-growth coniferous trees (Nelson 1997). This species shows no sexual dimorphism and is impossible to sex visually in the field (Hull, Vanderkist, et al. 2001). Thus, there is little information on relative provisioning of young by males and females in this species. However, Vanderkist et al. (1999) suggested that provisioning in Marbled Murrelets may not be equally distributed between male and female parents. They reported a significant male bias in birds captured while flying between marine foraging areas and inland nesting areas during July and August, when most breeding birds are feeding young (Lougheed 2000). However, birds captured in marine areas showed no bias in sex ratio (Vanderkist et al. 1999). Analyses of the egg precursor protein vitellogenin indicated only $2 \%$ of females ( $n=100$ birds) from the male-biased sample were producing eggs at the time of capture (Vanderkist et al. 2000, LAMT, unpubl. data). Vanderkist et al. (1999) also reported an increase in the male bias of their capture sample as the breeding season progressed. 
In this paper we report on relative nest site visits of male and female radio-marked Marbled Murrelets during the chick rearing period in Desolation Sound from 1998-2000. Our aim was to test the hypothesis that the male bias of birds flying inland reported by Vanderkist et al. (1999) was due to an increased level of nest visits by male Marbled Murrelets relative to females. Vanderkist et al. (1999) also suggested an alternative hypothesis that additional males flying inland were nonbreeders prospecting for breeding sites or defending territories.

\section{METHODS}

Adult Marbled Murrelets were captured in Desolation Sound, British Columbia, Canada $\left(50^{\circ} 05^{\prime} \mathrm{N}\right.$, $124^{\circ} 40^{\prime} \mathrm{W}$ ) prior to nesting in April and May 19982000. Birds were captured from small boats at night using dip nets (Whitworth et al. 1997, Vanderkist et al. 1999) and fitted with subcutaneous anchor radiotransmitters (model 386, Advanced Telemetry Systems, Isanti, Minnesota), following methods of Newman et al. (1999) but without the use of anesthetic. Trace blood samples $(<0.1 \mathrm{~mL})$ were taken and birds were sexed after the field season using genomic DNA subjected to PCR amplification (Griffiths et al. 1996, Vanderkist et al. 1999).

\section{RADIO-TRACKING}

Nest locations and incubation status of Marbled Murrelets were determined by aerial helicopter telemetry (Hull, Kaiser, et al. 2001). Daily marine detections of birds from early May to early August were used to determine the breeding status of each bird and to determine initiation of breeding, as incubating Marbled Murrelet pairs alternate regular 24-hr incubation shifts and exchange duties at dawn (Nelson 1997). Therefore, an incubating bird shows a regular pattern of marine detections every second day. Behavioral inferences from these attendance patterns at marine and nest locations, and analysis of the egg precursor protein vitellogenin in blood-sampled individuals, suggested that all radio-marked birds used in these analyses were captured prior to or during incubation.

We estimated hatch date as the date when parents switched from being present at nest sites during the day to visiting their nests mainly at dawn and dusk to feed their young. The period between suspected laying and hatching was approximately 30 days, consistent with other reports of incubation duration for the species (Nelson 1997). Radio-marked birds were monitored inland at nest sites and along flyways adjacent to nest sites. Nests were classified as active during chick rearing if they were visited at least once every $48 \mathrm{hr}$ by radio-marked parents. We ensured that radios of all birds used in our nest visitation analyses were functioning properly by only including data from birds with regular daytime marine detections throughout their chick-rearing period.

Nest-site monitoring was conducted by human observers in all years and also by remote data loggers (model DCC II, Advanced Telemetry Systems) in 2000. Observers conducted AM (03:30-7:30 PDT) and PM (20:00-24:00 PDT) radio-monitoring sessions coinciding with the peak times of chick-provisioning trips (Nelson 1997, Manley 1999). Both methods re- lied on an antenna (Advanced Telemetry Systems, four-element and $\mathrm{H}$ antennae) and a radio receiver (model R4000, Advanced Telemetry Systems). Static radio-monitoring was conducted at locations near nest sites ( $\sim 0.5 \mathrm{~km}$ from the nest) or along flyways downstream from target nest sites. Both methods recorded the time a radio-marked bird was first and last detected, and counted detections of birds flying in and then out of a valley as one nest visit. To maximize the probability of detecting birds traveling up watersheds, flyway monitoring stations were often positioned at the height of land along ridgelines and subalpine plateaus. Human observers recorded the direction and signal strength of a detection every few minutes. This information was used to determine the location and movement direction of a radio-marked bird. Data loggers recorded similar data, except for movement direction. Due to the reduced directionality in the data-logger results, antennae were oriented to target specific watersheds. To further reduce bias in the data-logger data, "dummy frequencies" were used to ensure that data were not corrupted by interference. Data loggers were not used in coastal areas or on ridges within $5 \mathrm{~km}$ of the ocean to avoid falsely classifying a bird flying over the ocean as traveling inland. Coastal nests were monitored by human observers stationed in a location where they could distinguish presence of birds on the ocean or at the nest.

At the completion of each breeding season, 15 accessible nest trees (of 46 total) were climbed to investigate nest sites and determine true fledging success (Hamer et al. 1994, Manley 1999).

\section{STATISTICAL ANALYSIS}

A total of 48 birds (23 females, 25 males) were used in these analyses. For each adult at each nest, we determined a rate of AM, PM, and overall detections relative to the number of observation sessions for that individual. Results across years were pooled to test three predictions about nest visitation. First, that overall rates of nest visits by males during the chick-rearing period were greater than females (Vanderkist et al. 1999). Second, that PM rates of nest visits by males were greater than those of females, and by a greater margin than in AM visits. Third, that male-biased nest visitation by males increased over the breeding season (Vanderkist et al. 1999).

To test the third hypothesis, we divided observations into early or late chick-rearing for each bird. Early chick-rearing was defined as the first 15 days postincubation, given that murrelets usually have a 30-day chick-rearing period (Nelson 1997). We examined these seasonal, within-sex differences both within and among individuals. Individuals with known visitation rates in both early and late chick rearing were compared in a paired analysis, separate from within-sex comparisons of different individuals in the two stages of chick-rearing.

We used $t$-tests when data were normally distributed (Anderson Darling test) and nonparametric MannWhitney-Wilcoxon tests when data were not normally distributed. When testing the hypotheses that females visited nest sites less often than males, we used onetailed tests. A chi-square test was used to test for increased male bias in evening captures of birds flying 
TABLE 1. Male and female Marbled Murrelet nest visitation rates during early and late chick rearing. Visitation rates are mean \pm SE number of detections per 4-hr observation session. Tests for differences in visitation rates between sexes and among individuals were conducted with all available independent datapoints. Reported sample sizes are subsets of the total number of birds tracked ( 23 females, 25 males). Unless noted, all tests are onetailed. Early = nestling days $1-15$; late = nestling days 16-30.

\begin{tabular}{|c|c|c|c|}
\hline & Female $(n)$ & Male $(n)$ & $P$ \\
\hline \multicolumn{4}{|c|}{ Female vs. male } \\
\hline Early & $0.62 \pm 0.05(16)$ & $0.73 \pm 0.06(17)$ & $>0.09$ \\
\hline \multirow[t]{2}{*}{ Late } & $0.43 \pm 0.05(16)$ & $0.59 \pm 0.08$ & 0.05 \\
\hline & Early $(n)$ & Late $(n)$ & \\
\hline \multicolumn{4}{|c|}{ Within sex, among individuals } \\
\hline Female $^{\mathrm{a}}$ & $0.67 \pm 0.08$ & $0.41 \pm 0.07(7)$ & $<0.02$ \\
\hline Male & $0.83 \pm 0.08(10)$ & $0.62 \pm 0.09(8)$ & 0.11 \\
\hline \multicolumn{4}{|c|}{ Within individuals ${ }^{\mathfrak{c}}$} \\
\hline Female & $0.59 \pm 0.06(9)$ & $0.45 \pm 0.08$ & $<0.04$ \\
\hline Male & $0.58 \pm 0.07(7)$ & $0.55 \pm 0.13(7)$ & 0.87 \\
\hline
\end{tabular}

a Two-sample $t$-tests.

b Mann-Whitney-Wilcoxon test.

c Paired $t$-tests.

d Two-tailed test.

inland during chick-rearing relative to morning captures. A significance level of 5\% was used for statistical tests. Results are presented as means \pm SE. All analyses were done with Minitab release 13.1 (2000).

\section{RESULTS}

On average we conducted $11.0 \pm 2.0$ observation sessions per male and $12.1 \pm 1.7$ per female per year over three years of study. Thirty-three percent of sample birds were monitored throughout early and late chick rearing, while the remainder were observed only during one-half of their chick-rearing period. The mean total observation period was 11.6 days per bird. Males visited their nests 1.3 times as often as females $\left(t_{45}=2.4, P=0.01\right)$. The discrepancy between male and female visitation rates was even greater ( 1.8 times) during evening visits $(W=710.5, P=0.02, n=23$ females, 25 males). Both within and among individuals, male visitation rates did not significantly differ between early and late chick-rearing, while female visitation rates significantly decreased between these two periods (Table 1). In addition, male and female visitation rates did not significantly differ in early chick rearing, but female rates were significantly lower than those of males during late chick rearing (Table 1). All 15 of the nest trees we climbed showed evidence of a nest, including chick feces and down.

We had continuous late-chick-rearing monitoring data on only one of the two nests where both parents were radio-marked. In the final eight days of chickrearing at this successful nest, the male visited the nest 2.3 times as often as the female $(n=23$ total visits by both parents). Eighty-six percent ( 6 of 7) of the female's visits were AM feedings compared to $63 \%$ (10 of 16) for the male.

Although Vanderkist et al. (1999) found no significant difference in male bias between the morning and evening captures of birds flying inland at Theodosia Inlet, we reanalyzed the capture data with an additional two years of results. Pooling capture data (1994-1999, $n=680$ ), male bias in birds flying inland during the likely chick-rearing period was greater in the PM $(2.29: 1)$ than in the AM $\left(1.64: 1 ; \chi^{2}{ }_{1}=9.1, P<0.01\right)$.

\section{DISCUSSION}

Male Marbled Murrelets were detected visiting or traveling toward active nests during the chick-rearing period significantly more often than females. This trend was greater during trips made at dusk. During the late chick-rearing period, females significantly reduced their rate of nest visitation, both within and between individuals. These results support the hypothesis that previous findings of male bias in birds flying inland were at least partly due to male-biased provisioning in this population of Marbled Murrelets (Vanderkist et al. 1999).

Most sightings of adult birds at active nests during the chick-rearing period are associated with provisioning (P. Jones 1993, Nelson and Hamer 1995, Nelson 1997), with the only noted exception involving disturbance from predator calls played by human observers (T. Hamer, pers. comm.). Therefore, we assume the nest visits we have recorded indicate chick-provisioning trips. Tree-climbing observations of evidence of chicks and chick-feeding at all our accessible active nests support this assumption. Still, some nest visits by breeding birds may not involve provisioning and may involve activities like territory defense, as observed in other alcids (Wanless and Harris 1986). The role of breeding territory defense in the noncolonial Marbled Murrelet is unknown (Nelson 1997). However, even if some male visits to nest sites are not provisioning trips, these males still expend more energy than females for this aspect of reproductive effort. 
Sex-biased provisioning in altricial birds takes many forms. Male-biased provisioning is observed in several seabird species, including many larids (Fasola and Saino 1995) and albatrosses (Huin et al. 2000, Weimerskirch et al. 2000). However, this pattern is reversed in most studies of the Alcidae. Creelman and Storey (1991) found female Atlantic Puffins (Fratercula arctica) making more chick-provisioning visits than males. A similar trend has been observed in Common Murres (Uria aalge; Wanless and Harris 1986) and Crested Auklets (Aethia cristatella; I. Jones 1993). However, male puffins and murres are involved in much more territory defense during the breeding season than females (Creelman and Storey 1991, Wanless and Harris 1986). Increased territory defense by males was observed throughout the breeding period, primarily pre-egg-laying in murres and during chick rearing in puffins (Creelman and Storey 1991, Wanless and Harris 1986). Thus, contrasting sex biases are observed in allocation of resources for different aspects of reproductive effort. If male Marbled Murrelets do not invest in territorial behavior to the same extent as male alcids of colonial species, perhaps they have more energetic resources to devote to provisioning.

While our results on overall feeding bias are opposite to findings for most other alcids, a study of Dovekies (Alle alle) showed male provisioning bias late in chick-rearing. While female Dovekies provide the majority of chick provisioning until late chick-rearing, they cease provisioning about five days before the chick fledges, after which the male does all feeding (Taylor and Konarzewski 1992).

The overall male bias of inland trips by confirmed breeders reported here (1.3 times) is markedly less than the 1.8 times male bias reported by Vanderkist et al. (1999). Our result may be due to our limited sample of birds of known sex and breeding status. As suggested by Vanderkist et al. (1999), there may also be a male bias in nonbreeding birds flying inland to prospect for breeding sites or defend territories. Our radiotelemetry surveys have focused on breeding birds, but there is a need for future study to quantify the inland behavior of known nonbreeders.

The decrease in female effort during the late chickrearing period is similar to trends observed in other birds outside the Alcidae, such as Pacific Loons (Gavia pacifica; Petersen 1989) and Merlins (Falco columbarius; Sodhi 1993). The behavioral change observed in Marbled Murrelets may be due to the likely high cost of egg production in this species. Marbled Murrelet eggs are approximately $20 \%$ of adult body mass (Nelson 1997), in addition to the mass increase and energetic cost of ovary development to females for their one-egg clutch. Monaghan et al. (1998) showed that parental effort is mediated through the negative influence of egg production on female condition. Therefore, the decrease in female investment during the chick-rearing period may result from more female self-feeding to recover egg production costs. However, there is little empirical evidence that supports an immediate "egg cost" hypothesis in murrelets. After egg laying, female Marbled Murrelets show no mass declines throughout the breeding season (Sealy 1975). In addition, females share incubation duties equally with males (Nelson 1997) and appear to decrease their investment in provisioning only during the latter half of the 30-day chick-rearing period. Therefore, females apparently invest in reproduction as much as males do for approximately 45 days post-laying. This suggests two hypotheses. First, that egg production is energetically costly to females but that payment of this cost can be deferred. Under this scenario, female energetic reserves for reproduction are not depleted until the late chick-rearing stage, leaving males as primary provisioners. Alternatively, there may be an advantage to females in decreasing their reproductive effort late in chick rearing which is independent of breeding. Other costly activities, such as post-breeding molt, may be adversely affected by prolonged breeding effort (Dawson et al. 2000). In addition, a change in food availability or accessibility for Marbled Murrelets late in the breeding season, as observed in Prince William Sound, Alaska (K. Kuletz, pers. comm.), could make foraging more costly, with females reaching a threshold at which their energetic deficit must be addressed. However, a reduction in prey availability appears to be unlikely in Desolation Sound, as birds remain in the area after the breeding season to molt in the same marine areas they occupy during the summer (N. Parker, pers. comm.).

On a broader scale, these results may help to explain common behavior patterns observed in inland monitoring of Marbled Murrelets. In most observations of chick feedings and murrelet activity in potential breeding habitat during the chick-rearing period, there are fewer detections at dusk than at dawn from standard surveys (Nelson 1997, Manley 1999) and radar monitoring (Burger 1997). Assuming that parents provide equal feeding loads throughout the chick-rearing period, and that there is no mean increase in prey size, the reduction in female nest visitation we observed may correspond to the marked drop in feeding rate by Marbled Murrelet parents just prior to fledging ( $\mathrm{P}$. Jones 1993, Nelson and Hamer 1995). This phenomenon is seen in many alcids and other seabird species (Gaston and Jones 1998).

A general increase in inland audiovisual detections of murrelets in July has been widely reported throughout most of the species' range (O'Donnell 1993, Rodway et al. 1993, Manley 1999, Jodice and Collopy 2000). Most of our study birds were in the late chickrearing phase during the month of July. Therefore, our findings of reduced overall nest visitation in late-chick rearing offer support for the hypothesis that this increase in Marbled Murrelet inland detections during July is due to the influx of nonbreeding or prospecting birds and not chick-rearing breeders. Our study demonstrates the interpretive advantage gained when we can follow individuals over extended periods. In a species of such strong management concerns (Nelson 1997), it is imperative that basic breeding ecology is well understood, in order to develop the most informed, progressive management policy possible.

We thank the tireless field crews who stayed out all night catching birds and got up too early in order to monitor radios in many precarious locations. We thank D. Taylor and E\&B Helicopters for logistical support. 
K. Kuletz and B. A. Cooper provided very useful comments and suggestions on an earlier draft of this paper. R. W. Stein assisted with statistical advice. G. Fernandez-Aceves helped with the Spanish translation of the abstract. This work was funded by Forest Renewal British Columbia through Multi-Year Agreements and the Science Council of British Columbia, Natural Sciences and Engineering Council, Canadian Wildlife Service, Weyerhaeuser Canada and Weyerhaeuser Inc., International Forest Products Ltd., Western Forest Products Ltd., TimberWest Forest Ltd., and National Council of the Paper Industry for Air and Stream Improvement.

\section{LITERATURE CITED}

Burger, A. E. 1997. Behavior and numbers of Marbled Murrelets measured with radar. Journal of Field Ornithology 68:208-223.

Clutton-Brock, T. H. 1991. The evolution of parental care. Princeton University Press, Princeton, NJ.

Creelman, E., And A. E. Storey. 1991. Sex differ ences in the reproductive behavior of Atlantic Puffins. Condor 93:390-398.

$\rightarrow$ Dawson, A., S. A. Hinsley, P. N. Ferns, R. H. C. BONSER, AND L. ECCLESTON. 2000. Rate of moult affects feather quality: a mechanism linking current reproductive effort to future survival. Proceedings of the Royal Society of London Series B 267:2093-2098.

Fasola, M., And N. Saino. 1995. Sex-biased parental care allocation in three tern species (Laridae, Aves). Canadian Journal of Zoology 73:14611467.

Gaston, A. J., AND I. L. JonEs. 1998. The auks. Oxford University Press, Oxford, UK.

$\rightarrow$ Griffiths, R., S. DaAn, And C. Dijkstra. 1996. Sex identification in birds using two CHD genes. Proceedings of the Royal Society of London Series B 263:1251-1256.

Hamer, T. E., S. K. Nelson, A. K. Hubbart, S. K. Hughes, R. W. Becking, J. G. Hardin, K. J. KuLETZ, N. L. NASLUND, AND S. SINGER. 1994. Guidelines for collecting data at Marbled Murrelet nest trees or landing trees. Pacific Seabird Group Marbled Murrelet Technical Committee, P.O. Box 2498, Smithers, BC V0J 2N0, Canada.

Huin, N., P. A. Prince, And D. R. Briggs. 2000. Chick provisioning rates and growth in Black-browed Albatross Diomedea melanophris and Grey-headed Albatross D. chrysostoma at Bird Island, South Georgia. Ibis 142:550-565.

$\rightarrow$ Hull, C. L., G. W. Kaiser, C. Lougheed, L. LougHEED, S. BOYD, AND F. COOKE. 2001. Intra-specific variation in commuting distance of Marbled Murrelets Brachyramphus marmoratus: ecological and energetic consequences of nesting further inland. Auk 118:1036-1047.

$\rightarrow$ Hull, C. H., B. Vanderkist, L. Lougheed, G. Kaiser, AND F. COOKE. 2001. Morphometric variation in Marbled Murrelets in British Columbia. North western Naturalist 82:41-51.

Jodice, P. G. R., AND M. W. Collopy. 2000. Activity patterns of Marbled Murrelets in Douglas-fir old growth forests of the Oregon Coast Range. Condor 102:275-285.

JoNES, I. A. 1993. Crested Auklet (Aethia cristatella). In A. Poole and F. Gill [EDS.], The birds of North America, No. 70. The Academy of Natural Sciences, Philadelphia, PA, and The American Ornithologists' Union, Washington, DC.

JoNES, P. 1993. Canada's first active Marbled Murrelet nest, Sechelt Peninsula, BC. Discovery 22:147150.

LOuGHEED, C. L. 2000. Breeding chronology, breeding success, distribution and movements of Marbled Murrelets (Brachyramphus marmoratus) in Desolation Sound, British Columbia. M.Sc. thesis, Simon Fraser University, Burnaby, BC, Canada.

MANLEY, I. A. 1999. Behaviour and habitat selection of Marbled Murrelets nesting on the Sunshine Coast. M.Sc. thesis, Simon Fraser University, Burnaby, BC, Canada.

MINITAB. 2000. Minitab statistical software, release 13.1. Minitab, Inc., State College, PA.

Monaghan, P., R. G. Nager, and D. C. Houston. 1998. The price of eggs: increased investment in egg production reduces the offspring rearing capacity of parents. Proceedings of the Royal Society of London Series B 265:1731-1735.

Nelson, S. K. 1997. Marbled Murrelet (Brachyramphus marmoratus). In A. Poole and F. Gill [EDS.], The birds of North America, No. 276. The Academy of Natural Sciences, Philadelphia, PA, and The American Ornithologists' Union, Washington, DC.

Nelson, S. K., AND T. E. HAMER. 1995. Nesting biology and behavior of the Marbled Murrelet, p. 5768. In C. J. Ralph, G. L. Hunt Jr., M. G. Raphael, and J. F. Piatt [EDS.], Ecology and conservation of the Marbled Murrelet. USDA Forest Service General Technical Report PSW-GTR-152.

Newman, S. H., J. Y. TakeKawa, D. L. Whitworth, AND E. E. BurketT. 1999. Subcutaneous anchor attachment increases retention of radio transmitters on Xantus' and Marbled Murrelets. Journal of Field Ornithology 70:520-534.

O'Donnell, B. P. 1993. Patterns of activity and vocalizations of the Marbled Murrelet, Brachyramphus marmoratus, within old growth redwood stands in northwestern California. M.Sc. thesis, Humboldt State University, Arcata, CA.

Petersen, M. R. 1989. Nesting biology of Pacific Loons (Gavia pacifica) on the Yukon-Kuskokwim Delta, Alaska. Canadian Field Naturalist 103:265269.

Pettingill, O. S. 1970. Ornithology in laboratory and field. Burgess Publishing, Minneapolis, MN.

Rodway, M. S., H. M. Regehr, and J. P. L. Savard. 1993. Activity patterns of Marbled Murrelets in old-growth forests in the Queen Charlotte Islands, British Columbia. Condor 95:831-848.

RofF, D. A. 1992. The evolution of life histories: theory and analysis. Chapman and Hall, New York.

Sealy, S. G. 1975. Aspects of the breeding biology of the Marbled Murrelet in British Columbia. BirdBanding 46:141-154.

SoDHI, N. S. 1993. Proximate determinates of foraging 
effort in breeding male Merlins. Wilson Bulletin 105:68-76.

TAYLOR, J., AND L. KonARZEWSKI. 1992. Budget of elements in Little Auk (Alle alle) chicks. Functiona Ecology 6:137-144.

VANDERKIST, B. A., T. D. Williams, D. F. Bertram, L. W. LOUGHEED, AND J. L. RYDER. 2000. Indirect physiological assessment of reproductive state and breeding chronology in free-living birds: an example in the Marbled Murrelet (Brachyramphus marmoratus). Functional Ecology 14:758-765.

Vanderkist, B. A., X. H. Xue, R. Griffiths, K. MarTIN, W. BeaUchamp, and T. D. Williams. 1999.
Evidence of male bias in capture samples of Marbled Murrelets from genetic studies in British Columbia. Condor 101:398-402.

WANLess, S., AND M. P. HaRris. 1986. Time spent at the colony by male and female Guillemots Uria aalge and Razorbills Alca torda. Bird Study 33:168-176.

WeImERSKIRCH, H., C. BARBRAUD, AND P. LYS. 2000. Sex differences in parental investment and chick growth in Wandering Albatross: fitness consequences. Ecology 81:309-318.

Whitworth, D. L., J. Y. Takekawa, H. R. Carter, AND W. R. MCIVER. 1997. A night-lighting technique for at sea capture of Xantus' Murrelets. Colonial Waterbirds 20:525-531.

\title{
FEEDING OF HOUSE WREN NESTLINGS AFFLICTED BY HEMATOPHAGOUS ECTOPARASITES: A TEST OF THE PARENTAL COMPENSATION HYPOTHESIS
}

\author{
Brian L. MORRISON AND L. SCOTT JOHNSON ${ }^{1}$ \\ Department of Biology, Towson University, Towson, MD 21252
}

\begin{abstract}
This study asked whether parent House Wrens (Troglodytes aedon) in a Wyoming population increased rates of food delivery to broods parasitized by hematophagous blow fly larvae and mites. We observed no significant difference in rates at which pairs fed nestlings at nests with naturally heavy infestations of fly larvae (6-19 larvae per nestling) and nests in which nestling exposure to larvae was experimentally eliminated or severely reduced (0-2 larvae per nestling). The apparent failure of parents to compensate nestlings for resources lost to parasites may, in part, explain the reduced rates of mass gain by parasitized nestlings that we observed and the presence of reduced hemoglobin levels in parasitized nestlings documented in a companion study. Parasitized nestlings may be too weak or anemic to intensify begging activity which would alert parents to their increased need for food.
\end{abstract}

Key words: bird blow fly, ectoparasitism, House Wren, nestling growth, parental care, Protocalliphora parorum, Troglodytes aedon.

\section{Alimentación de Polluelos de Troglodytes aedon Afectada por Ectoparásitos Hematófagos: Una Prueba de la Hipótesis de Compensación Parental}

Manuscript received 9 January 2001; accepted 13 August 2001

${ }^{1}$ Corresponding author. E-mail: sjohnson@towson. edu
Resumen. Nos preguntamos si los individuos parentales de Troglodytes aedon de una población de Wyoming aumentan las tasas de alimentación sobre polluelos parasitados por ácaros y larvas de moscas hematófagas. No observamos diferencias significativas en la tasa a la cual las parejas alimentaron a los polluelos entre nidos altamente infectados naturalmente por la larva de la mosca (6-19 larvas por polluelo) y nidos en que la exposición a las larvas fue eliminada o severamente reducida experimentalmente (0-2 larvas por polluelo). En parte, la aparente falta de compensación por parte de los padres sobre la pérdida de recursos de los polluelos infectados puede explicar sus bajas tasas de ganancia de peso y los niveles reducidos de hemoglobina documentados en un estudio asociado al presente. Los polluelos parasitados probablemente se encuentran muy débiles o anémicos como para intensificar la actividad de reclamo lo que alertaría a los padres sobre su mayor necesidad de alimento.

Larvae of blow flies in the genus Protocalliphora (Diptera: Calliphoridae) feed on the blood of nestlings in a wide variety of bird species with altricial young throughout the Holarctic region (Sabrosky et al. 1989). Although blow fly parasitism reduces nestling survival, growth, or health in some populations, in other populations nestlings reportedly are little affected by larval feeding (e.g., Johnson and Albrecht 1993, Merino and Potti 1995, Hurtrez-Boussès et al. 1997, Miller and Fair 1997). One hypothesis for a lack of negative effects of parasites on nestlings is that parent birds com- 